Mycologia, 97(1), 2005, pp. 254-262.

(C) 2005 by The Mycological Society of America, Lawrence, KS 66044-8897

\title{
Symbiotic Harpellales (Trichomycetes) in Tasmanian aquatic insects
}

Leonard C. Ferrington Jr. ${ }^{1}$

Department of Entomology, University of Minnesota, St. Paul, Minnesota 55108-6125

Robert W. Lichtwardt

Department of Ecology $\mathcal{E}$ Evolutionary Biology, University of Kansas, Lawrence, Kansas 66045-7534

Barbara Hayford

School of Natural E Social Sciences, Wayne State College, Wayne, Nebraska 68787

Marvin C. Williams

Department of Biology, University of Nebraska at Kearney, Kearney, Nebraska 68849-1140

Abstract: Surveys for symbiotic fungi in the guts of aquatic insect larvae (Trichomycetes: Harpellales) in Tasmania, Australia, resulted in the discovery of four new species: two in Gripopterygidae (Plecoptera) nymphs, Plecopteromyces leptoperlarum and P. trinotoperlarum, and two associated with Diptera larvae, Smittium magnosporum in Thaumaleidae and Stachylina dolichospora in Chironomidae. Previously described species of Harpellales from other localities are reported and new host records summarized. A key to all Tasmanian species of Harpellales is provided.

Key words: Australia, Diptera, Ephemeroptera, gut fungi, Plecoptera, Trichomycetes

\section{INTRODUCTION}

Australia has numerous endemic insects, including many with aquatic immature stages. Associated with several of these aquatic insects is a broad diversity of symbiotic gut fungi, some of which also might be endemic, as well as others that have more cosmopolitan distributions and broader host ranges (Lichtwardt and Williams 1990, 1992a, b, c; Williams and Lichtwardt 1993). Here we describe four new species of Tasmanian Harpellales, extend the known distributions of previously described harpellids, document new host records and provide a summary and key to currently known species in Tasmania.

\footnotetext{
Accepted for publication 29 June 2004.

${ }^{1}$ Corresponding author. E-mail: ferri016@umn.edu
}

\section{MATERIALS AND METHODS}

Immature aquatic insects were collected from streams, pools or seeps using nets or sieves or picked directly from the substrate, then transported alive on ice to the laboratory where they were dissected under a stereo microscope and studied in water mounts using Nomarski or phase contrast optics at higher magnifications. Fungal specimens were photographed, prepared as semipermanent slides by infiltrating lactophenol cotton-blue under the cover slip and sealing with clear fingernail polish; attempts were made to culture some of them. Culturing was done on dilute braininfusion agar medium with an overlay of water to which was added a Penicillin-Streptomycin antibiotic mixture (Lichtwardt et al 2001). Uncontaminated growth of the fungi subsequently was transferred to test tube slants without antibiotics and deposited in the University of Kansas Culture Collection. Type specimens of new species are deposited in the Farlow Herbarium (FH).

\section{NEW TAXA}

Plecopteromyces leptoperlarum. M.C. Williams \& Lichtwardt, sp. nov. Figs. 1-6

Thalli sparsim ramosi, series longam trichosporarum producentes. Trichosporae $12-21 \times 2-4 \mu \mathrm{m}$, curtae collare carentes, appendiculis duobus curtis interdum partim crispatis ornatae. Zygosporae ignotae. Thalli in proctodaeo nympharum Gripopterygidarum (Plecopterorum) affixi.

Thalli sparsely branched, producing long series of small trichospores without a collar, 12-21 × 2-4 $\mu \mathrm{m}$, with two short appendages that sometimes are partially curled. Zygospores unknown. Attached to hindgut of Gripopterygidae (Plecoptera) nymphs.

Etymology. Named after the host genus, Leptoperla.

Specimens examined. AUSTRALIA. Hobart Rivulet on Strickland Avenue at hairpin turn in road, Hobart, Tasmania, 11-III-91. Microscope slide AUS-93-M3 (HOLOTYPE: FH) in hindgut nymph of Leptoperla beroe Newman (Plecoptera: Gripopterygidae) from Site 93 (TABle I). Other collections from Site 104 (16-III-91), same location as Site 93.

This species is placed in the previously monotypic genus Plecopteromyces Lichtwardt, Ferrington \& López Lastra, despite the lack of zygospores because of trichospore morphology and host (see discussion section). The type species, Plecopteromyces patagoniensis Lichtwardt, Ferrington \& López Lastra, has trichospores measuring (25-) $33(-42) \times 5-7 \mu \mathrm{m}$ and thus are considerably larger than trichospores of $P$. lepto- 

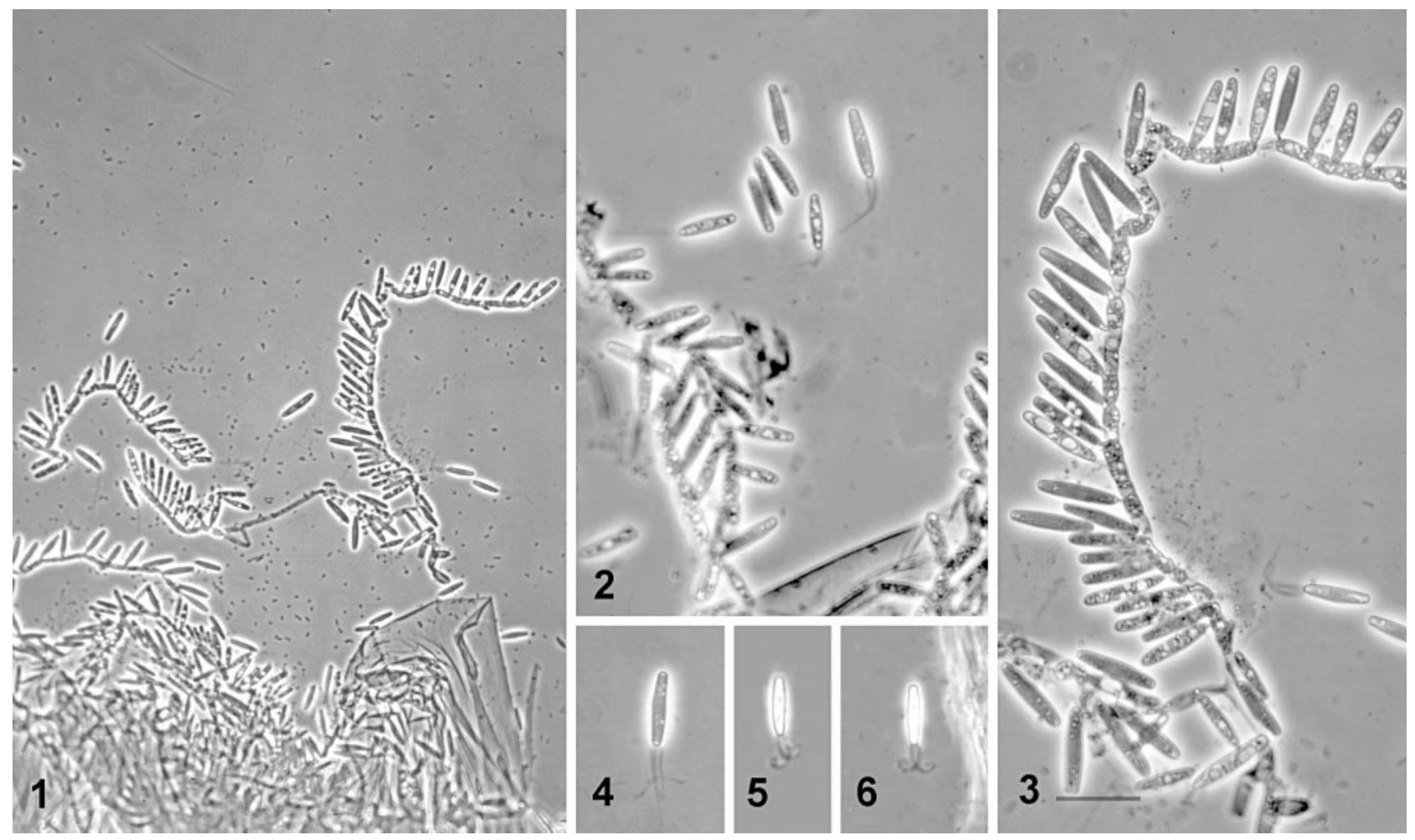

Figs. 1-6. Plecopteromyces leptoperlarum. 1-3. Arrangement of long series of trichospores on sporulating branchlets. 4-6. Released trichospores showing variation in the two basal appendages. Fig. 1 bar $=50 \mu \mathrm{m}$; Figs. $2-6$ bar $=20 \mu \mathrm{m}$.

perlarum. This new species also might have been found by Williams and Lichtwardt in Victoria, Australia, at several sites, although without released trichospores it is not possible to ascertain the nature of the appendages and identify the species. The collection sites in Victoria were: Murray River at Tom Groggin picnic area, 14-III-87; Lilly Pilly Gully, Wilsons Promontory, 7-III-89; Growlers Creek, Wilsons Promontory, 8-III-89; and Nankervis's Bridge (Rawe's Creek?) crossing the road leading south to Oureo, 13-III-87.

\section{Plecopteromyces trinotoperlarum M.C. Williams \&}

Lichtwardt, sp. nov.

FIGS. 7-12

Thalli series trichosporarum breves vel longas producentes. Trichosporae 21-30 × 3-5 $\mu \mathrm{m}$, collare carentes, appendiculis duobus curtis interdum inter se adhaerentibus praeditae. Zygosporae ignotae. Thalli in proctodaeo nympharum Gripopterygidarum (Plecopterorum) affixi.

Thalli producing short or long series of trichospores without a collar, $21-30 \times 3-5 \mu \mathrm{m}$, with two short appendages that sometimes adhere to each other. Zygospores unknown. Attached to hindgut lining of Gripopterygidae (Plecoptera) nymphs.

Etymology. Named after the host genus, Trinotoperla.

Specimens examined. AUSTRALIA. Henty River crossing Route A10, Tasmania, 18-III-91. Microscope slide AUS-107-
M1 (HOLOTYPE: FH) in hindgut nymph of Trinotoperla zwicki McLellan (Plecoptera: Gripopterygidae) from Site 107 (TABLE I). Other specimens from same host species and site as the Holotype.

The reason for placement of this species in the genus Plecopteromyces, though lacking zygospores, is treated in the Discussion section of this paper. The designation of $P$. trinotoperlarum as a new species is based on trichospore size. Collections of what may be nonsporulating thalli of this same hindgut fungus were found in nymphs of either T. zwicki or Trinotoperla hardyi Perkins in other sites in Tasmanian rivers: Russell River below Russell Falls, 7-III-91; Meander River in Meander Falls Reserve, 14-III-91; and Strickland Falls on Strickland Ave., Hobart, 16-III-91.

Smittium magnosporum Ferrington, Hayford \& Lichtw., sp. nov. Figs. 13, 14

Thalli haptero secreto praediti. Trichosporae longi-ellipsoidales, 36-47 × 9-10 $\mu \mathrm{m}$. collare campanulato 9-10 $\times 4-$ 5. Zygosporae ignotae. Thalli in proctodaeo larvarum Thamaleidarum (Dipterorum) affixi.

Thalli with a secreted holdfast. Trichospores longellipsoidal, 36-47 $\times 9-10 \mu \mathrm{m}$, with a campanulate collar 9-10 × 4-5 $\mu \mathrm{m}$. Zygospores unknown. Attached to hindgut lining of Thaumaleidae (Diptera) larvae. 
TABLE I. Summary of collection sites in Tasmania where Trichomycetes were found

\begin{tabular}{|c|c|c|c|c|}
\hline Site \# & Date & Lat/Long & Location & Body of Water/Notes/Water Temps \\
\hline 4 & 4-VIII-96 & $43^{\circ} 24.6 \mathrm{~S} / 146^{\circ} 52.2 \mathrm{E}$ & Hastings Rain Forest Park & small unnamed creek, temp $24 \mathrm{C}$ \\
\hline 10 & 8-VIII-96 & $42^{\circ} 21.6 \mathrm{~S} / 147^{\circ} 56.6 \mathrm{E}$ & Upstream highway bridge & $\begin{array}{l}\text { Ravensdale Rivulet, organic enrich- } \\
\text { ment from sheep, temp } 8 \mathrm{C}\end{array}$ \\
\hline 12 & 9-VIII-96 & $42^{\circ} 06.7 \mathrm{~S} / 148^{\circ} 15.7 \mathrm{E}$ & Cole's Bay Holiday Villas & $\begin{array}{l}\text { shallow tidal pool on rocks, temp } \\
8 \mathrm{C}\end{array}$ \\
\hline 17 & 12-VIII-96 & $43^{\circ} 05.0 \mathrm{~S} / 147^{\circ} 13.4 \mathrm{E}$ & Snug Falls & $\begin{array}{l}\text { near plunge pool at falls, temp } \\
7.5 \mathrm{C}\end{array}$ \\
\hline 18 & 12-VIII-96 & $43^{\circ} 05.0 \mathrm{~S} / 147^{\circ} 13.4 \mathrm{E}$ & Along path to Snug Falls & $\begin{array}{l}\text { small run-off pool along path, } \\
\text { temp } 8 \mathrm{C}\end{array}$ \\
\hline 20 & 12-VIII-96 & $43^{\circ} 08.6 \mathrm{~S} / 147^{\circ} 09.2 \mathrm{E}$ & & $\begin{array}{l}\text { Little Dennison River, upstream } \\
\text { bridge, temp } 7 \mathrm{C}\end{array}$ \\
\hline 21 & 14-VIII-96 & $42^{\circ} 10.4 \mathrm{~S} / 146^{\circ} 54.1 \mathrm{~S}$ & $\begin{array}{l}\text { A-5 Highway between } \\
\text { Steppes and Bothwell }\end{array}$ & Blackburn Creek, temp 5.5 C \\
\hline 24 & 16-VII-96 & $42^{\circ} 25.8 \mathrm{~S} / 146^{\circ} 38.3 \mathrm{E}$ & At A-10 bridge & Dee River, temp $6 \mathrm{C}$ \\
\hline 27 & 16-VIII-96 & $42^{\circ} 40.9 \mathrm{~S} / 146^{\circ} 42.9 \mathrm{E}$ & Russell Falls & $\begin{array}{l}\text { plunge pools } 3-20 \mathrm{~m} \text { below Russell } \\
\text { Falls, temp } 5.5 \mathrm{C}\end{array}$ \\
\hline 30 & 19-VIII-96 & $41^{\circ} 42.3 \mathrm{~S} / 146^{\circ} 45.9 \mathrm{E}$ & Liffey Falls & $\begin{array}{l}\text { downstream lower Liffey Falls, } \\
\text { temp } 6 \mathrm{C}\end{array}$ \\
\hline 32 & 19-VIII-96 & $41^{\circ} 39.3 \mathrm{~S} / 146^{\circ} 34.4 \mathrm{E}$ & $\begin{array}{l}\text { Near Leith's Creek, west of } \\
\text { Mother Cummins Peak }\end{array}$ & $\begin{array}{l}\text { unnamed stream, tributary of Me- } \\
\text { ander River, with some obvious } \\
\text { organic enrichment, temp } 7 \mathrm{C}\end{array}$ \\
\hline 33 & 19-VIII-96 & $41^{\circ} 39.4 \mathrm{~S} / 146^{\circ} 34.3 \mathrm{E}$ & Near Nell's Bluff & $\begin{array}{l}\text { Dale Creek, some obvious organic } \\
\text { enrichment, temp } 5.5 \mathrm{C}\end{array}$ \\
\hline 35 & 21-VIII-96 & $43^{\circ} 22.7 \mathrm{~S} / 147^{\circ} 19.4 \mathrm{E}$ & $\begin{array}{l}\text { First bridge on Lockley's } \\
\text { Road }\end{array}$ & Mavista Falls Creek, temp 7.5 C \\
\hline 36 & 21-VIII-96 & $43^{\circ} 18.9 \mathrm{~S} / 147^{\circ} 14.6 \mathrm{E}$ & North of Alonnah & small unnamed creek, temp $8 \mathrm{C}$ \\
\hline 37 & 23-VIII-96 & $42^{\circ} 08.5 \mathrm{~S} / 146^{\circ} 20.3 \mathrm{E}$ & At A-10 bridge & Clarence River, temp $4 \mathrm{C}$ \\
\hline 38 & 23-VIII-96 & $42^{\circ} 11.1 \mathrm{~S} / 146^{\circ} 09.1 \mathrm{E}$ & Upstream A-10 bridge & Navarre River, temp $4 \mathrm{C}$ \\
\hline 39 & 23-VIII-96 & $42^{\circ} 07.5 \mathrm{~S} / 145^{\circ} 50.0 \mathrm{E}$ & Downstream A-10 bridge & Cardigan River, temp $6 \mathrm{C}$ \\
\hline 41 & 23-VIII-96 & $42^{\circ} 06.2 \mathrm{~S} / 145^{\circ} 44.4 \mathrm{E}$ & Nelsen Falls & $\begin{array}{l}\text { pools } 20-25 \mathrm{~m} \text { downstream of falls, } \\
\text { temp } 7 \mathrm{C}\end{array}$ \\
\hline 42 & 24-VIII-96 & $40^{\circ} 56.6 \mathrm{~S} / 144^{\circ} 36.8 \mathrm{E}$ & West Point & $\begin{array}{l}\text { small rocky pools above high tide } \\
\text { line but subject to wave spray, } \\
\text { temp } 12 \mathrm{C}\end{array}$ \\
\hline 43 & 24-VIII-96 & $40^{\circ} 56.6 \mathrm{~S} / 144^{\circ} 36.8 \mathrm{E}$ & West Point & $\begin{array}{l}\text { shallow wetland away from rocky } \\
\text { high tide line, organically en- } \\
\text { riched by shorebird droppings, } \\
\text { temp } 9 \mathrm{C}\end{array}$ \\
\hline 50 & 29-VIII-96 & $42^{\circ} 55.3 \mathrm{~S} / 147^{\circ} 15.6 \mathrm{E}$ & $\begin{array}{l}\text { Just west of Fern Tree } \\
\text { along Highway B-64 }\end{array}$ & $\begin{array}{l}\text { small seep running across rock fac- } \\
\text { es near entrance to Fern Glade } \\
\text { park, temp } 9.5 \mathrm{C}\end{array}$ \\
\hline
\end{tabular}

Etymology. Latin magnus = large.

Specimens examined. AUSTRALIA. Seep along route B-64 at base of steps leading to Fern Glade just west of Fern Tree, Tasmania, 29-VIII-96. Microscope slide 50-1-7 (Ferrington, lab note designation) (HOLOTYPE: $\mathrm{FH}$ ) in hindgut of a Thaumaleidae larva from Site 50 (TABLE I). Other specimens are from same host and site as the Holotype. Possibly also from Site 35, Mavista Falls Creek at first bridge on Lockleys Road, Tasmania, 21-VIII-96.

This large-trichospored Smittium most closely resembles Sm. longisporum M.C. Williams, Lichtwardt \&
S.W. Peterson known from Chironomidae larvae in USA and northern Sweden, whose trichospore measurements are recorded as (40-)46(-55) × (6-)8(-10) $\mu \mathrm{m}$ with a fusiform-ellipsoidal shape (Williams et al 1982). The collar of Sm. longisporum, (10-)13(-17) $\times 4 \mu \mathrm{m}$, is on the average longer than that of $\mathrm{Sm}$. magnosporum, from which emanates a long, well defined and characteristically zigzagged appendage, a feature not found in the less conspicuous appendage of Sm. magnosporum. 

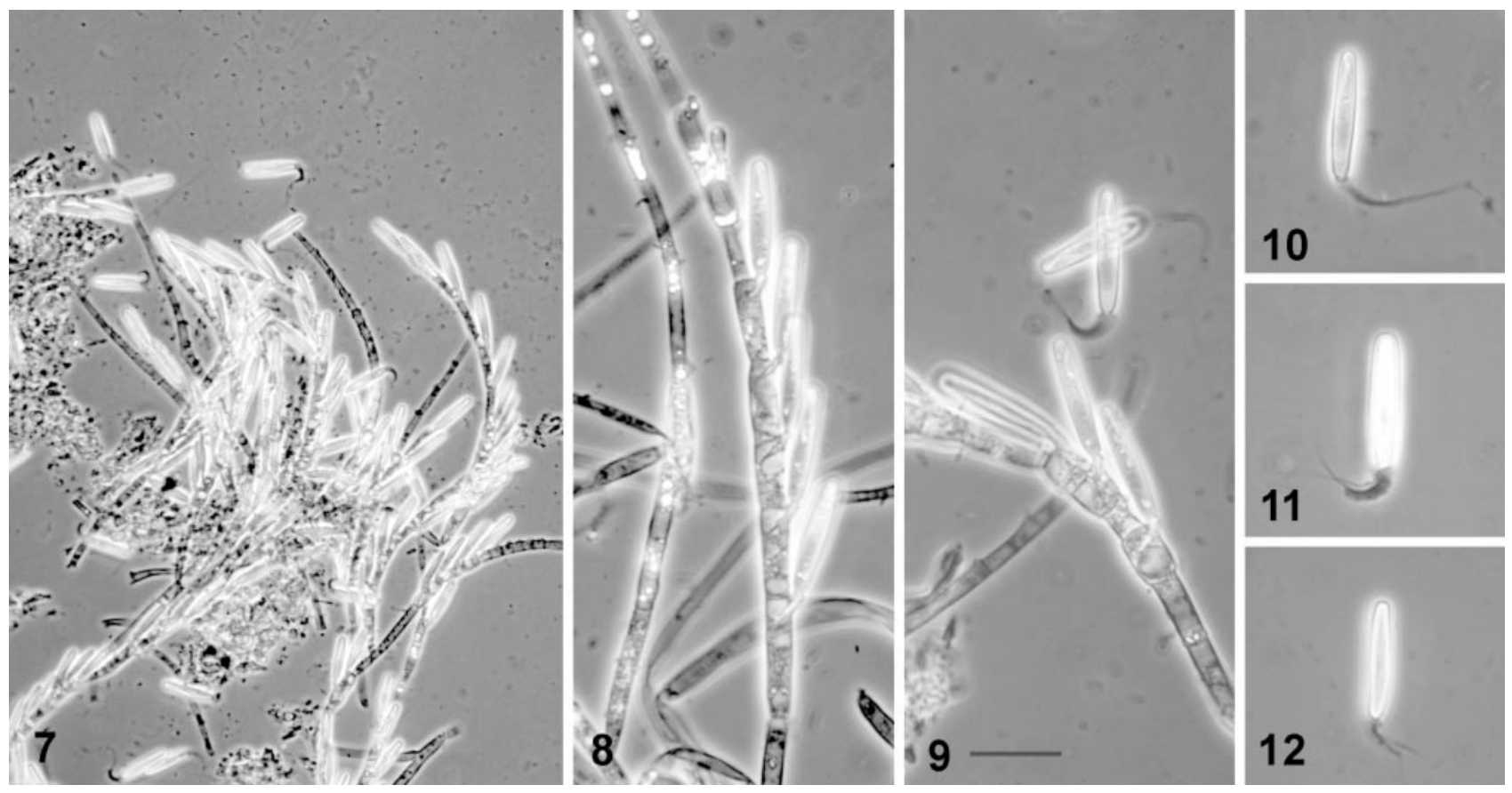

Figs. 7-12. Plecopteromyces trinotoperlarum. 7-9. Sporulating branchlets with attached and detached trichospores. 10-12. Detached trichospores showing the nature of the two appendages which sometimes are partially fused together. FiG. 7 bar $=50 \mu \mathrm{m}$; Figs. $9-12$ bar $=20 \mu \mathrm{m}$.

Stachylina dolichospora Ferrington, Hayford \& Lichtwardt, sp. nov.

FIGS. 15-17

Thalli plus quam $400 \mu \mathrm{m}$ longi $\times 8-11 \mu \mathrm{m}$ diametro. Trichosporae $(78-) 93(-108) \times 8-10 \mu \mathrm{m}$, collare ca. $2 \mu \mathrm{m}$ longo atque appendiculo curto robusto in bullam terminante praeditae. Thalli in membrana peritrophica larvarum Chironomidarum (Dipterorum) affixi.

Thalli $8-11 \mu \mathrm{m}$ diam by more than $400 \mu \mathrm{m}$ long. Trichospores $(78-) 93(-108) \times 8-10 \mu \mathrm{m}$, with a collar ca. $2 \mu \mathrm{m}$ long, and a short, stout appendage with a terminal knob. Attached to peritrophic membrane in midgut of Chironomidae (Diptera) larvae.

Etymology. Greek dolichos = long (spored).

Specimens examined. AUSTRALIA. Dale Creek at bridge of road west of West Creek, Tasmania, 19-VIII-96. Microscope slide 33-1-1 (Ferrington, lab note designation) (HOLOTYPE: FH) from peritrophic membrane of Riethia sp., a Chironomidae (Chironominae: Pseudochironomini) larva from Site 33 (TABLE I). Another larva from same site and genus as the Holotype.

This new Stachylina has trichospores longer than any other described species. The almost cylindrical shape is uncommon in the genus.

\section{PREVIOUSLY DESCRIBED SPECIES AND AXENIC CULTURES}

In addition to the new species described above other Harpellales have been collected in Tasmania. We have included all species known from Tasmania as a result of investigations by Ferrington and Hayford in
1996 and publications by Lichtwardt and Williams (1990, 1992b) (TABLE II). Eight axenic cultures of three species were isolated successfully in 1996, as indicated in the following text.

Austrosmittium biforme Lichtw. \& M.C. Williams (Lichtwardt and Williams 1992)

This species was found in the hindgut of a Paraheptagyia sp. larva from Site 17 and a Cricotopus sp. larva from Site 32 (TABLE I). A culture, 32-1-8, was obtained from a larva at Site 32. This culture was one of two Australian species used by Misra (2000) in a study of their growth, sporulation and $\mathrm{pH}$ tolerance. Originally thought to be an Australasian genus with two species in Australia (Lichtwardt and Williams 1990, 1992b) and two in New Zealand (Williams and Lichtwardt 1990), what appear to be species of Austrosmittium recently have been found in Orthocladiinae larvae in Kansas, USA (Ferrington and White unpubl) and unidentified larvae from Ontario, Canada (Strongman pers comm).

Harpella melusinae Léger \& Duboscq, 1929

One of the most widespread species of Harpellales, H. melusinae can be found attached to the peritrophic membrane of larvae in many populations of Simuliidae (blackflies) around the world (but at present is unknown in Central or South America, where oth- 


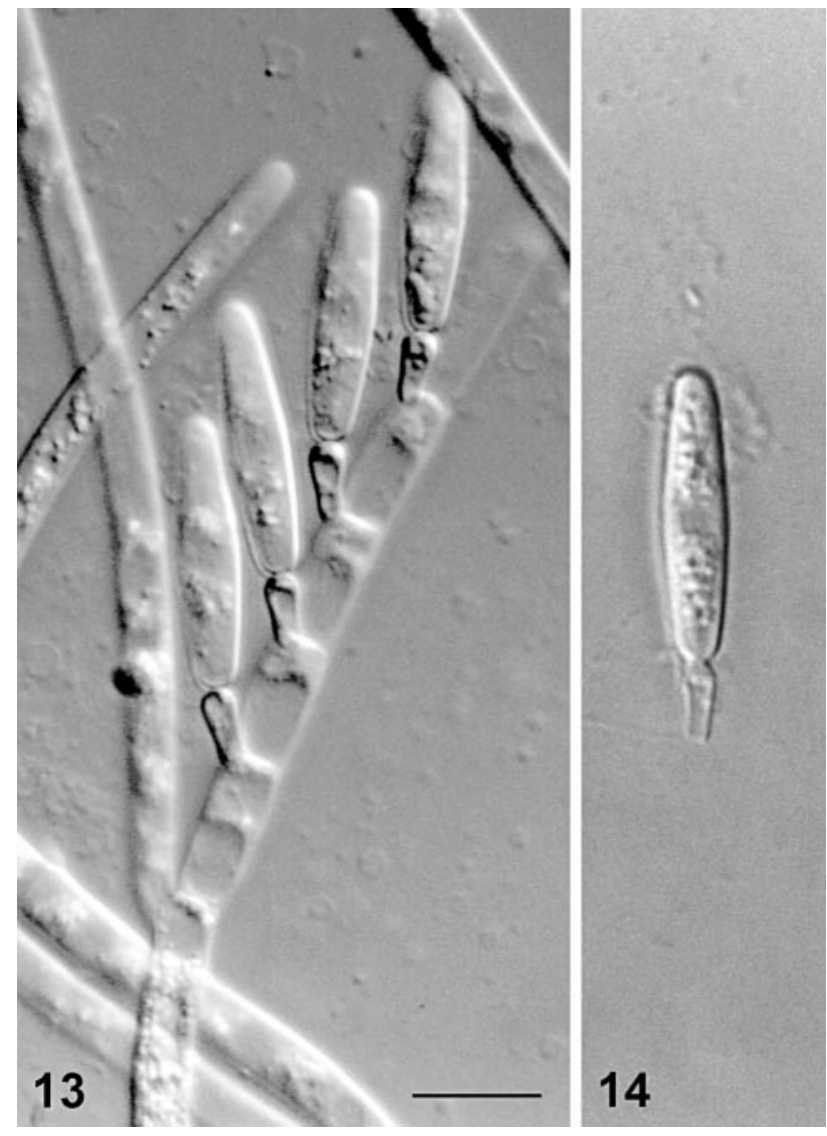

FIGS. 13, 14. Smittium magnosporum. 13. Attached trichospores. 14. Released trichospore with a collar but no appendage showing. Bar $=20 \mu \mathrm{m}$.
TABLE II. Harpellales currently known from larval aquatic insects in Tasmania

\begin{tabular}{|c|c|}
\hline \multicolumn{2}{|l|}{ Diptera } \\
\hline Ceratopogonidae & Smittium simulii \\
\hline \multirow[t]{11}{*}{ Chironomidae } & Austrosmittium aussiorum ${ }^{\mathrm{a}}$ \\
\hline & Austrosmittium biforme ${ }^{\mathrm{b}}$ \\
\hline & Furculomyces boomerangus ${ }^{\mathrm{a}}$ \\
\hline & Smittium compactum \\
\hline & Smittium culicis \\
\hline & Smittium fastigatum \\
\hline & Smittium paludis \\
\hline & Smittium simulii \\
\hline & Smittium typhellum \\
\hline & Stachylina dolichospora ${ }^{c}$ \\
\hline & Stachylina grandispora \\
\hline Culicidae & Smittium culicis \\
\hline \multirow[t]{3}{*}{ Simuliidae } & Harpella melusinae \\
\hline & Simuliomyces microsporus \\
\hline & Smittium simulii \\
\hline \multirow[t]{4}{*}{ Thaumaleidae } & Smittium culicis \\
\hline & Smittium magnosporum ${ }^{c}$ \\
\hline & Stachylina thaumaleidarum ${ }^{\mathrm{a}}$ \\
\hline & Smittium simulii \\
\hline \multicolumn{2}{|l|}{ Ephemeroptera } \\
\hline Baetidae & Glotzia tasmaniensis \\
\hline \multicolumn{2}{|l|}{ Plecoptera } \\
\hline \multirow[t]{2}{*}{ Gripopterygidae } & Plecopteromyces leptoperlarum ${ }^{\mathrm{a}, \mathrm{c}}$ \\
\hline & Plecopteromyces trinotoperlarum \\
\hline
\end{tabular}

a Species known only from Australia.

b Species in boldface are known only from Tasmania.

${ }^{\mathrm{c}}$ New species described in this paper.
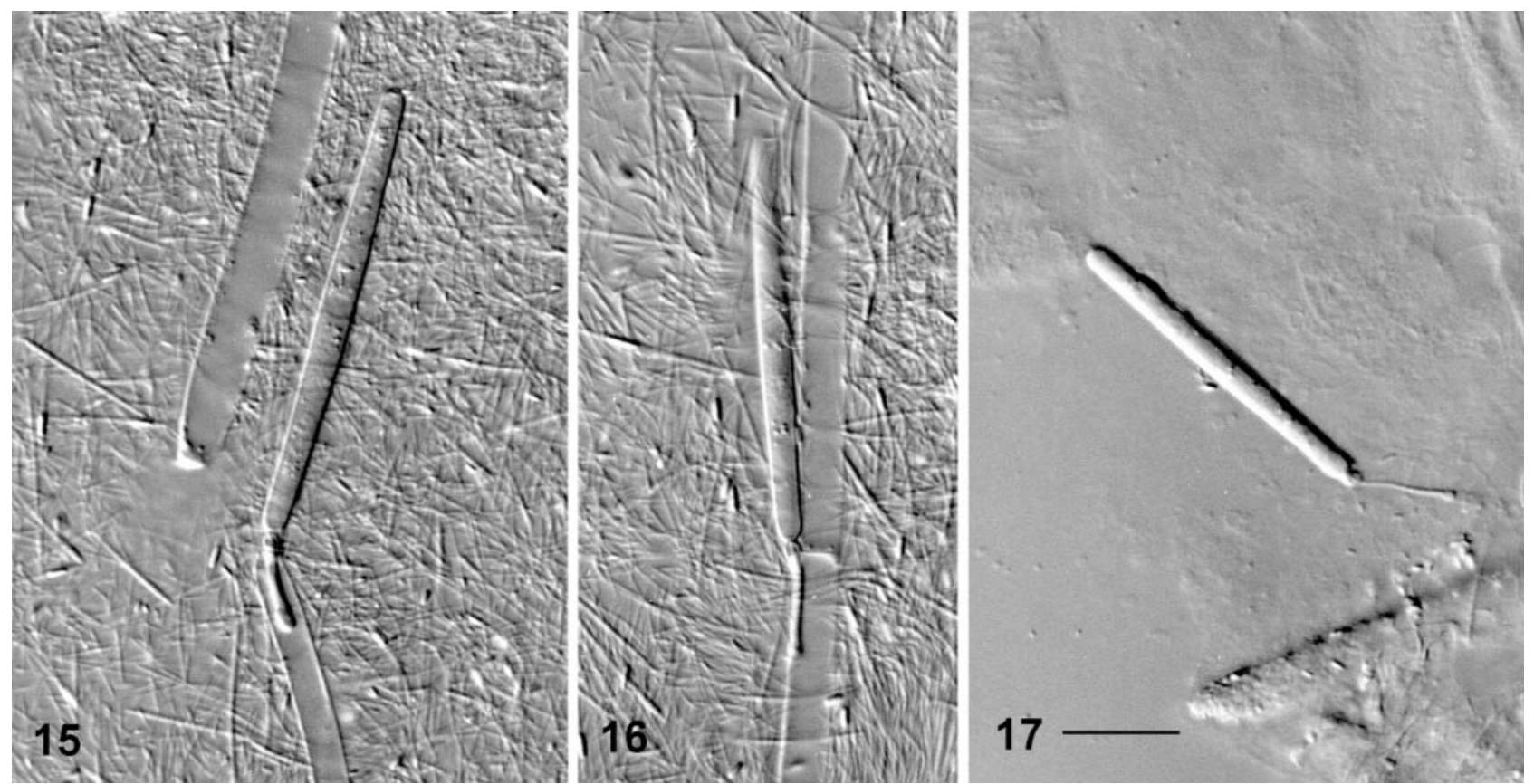

Figs. 15-17. Stachylina dolichospora. 15, 16. Attached trichospores with appendage visible within the generative cell. 17. Released trichospore with a short collar and appendage. Bar $=20 \mu \mathrm{m}$. 
er species of Harpella are common [Lichtwardt et al 2001]). For instance, it appears to be capable of living in larvae of most species of blackflies in the southeastern United States (Beard et al 2003). New reports from various species of Tasmanian Simuliidae include Sites 17, 36, 38 and 46.

\section{Smittium culicis Manier, 1970}

Another cosmopolitan species of Harpellales, Sm. culicis, has been found to inhabit larval hindguts of a number of Diptera families (Lichtwardt et al 2001). In Tasmania new reports include Site 12 (in Culicidae), Sites 20 and 35 (in Thaumaleidae), Site 42 in Cricotopus sp. (Chironomidae) and Site 43 in Chironomus sp. (Chironomidae). Six axenic cultures were obtained, four from Site 12 (isolates 12-1-1, 12-1-2, 12-1-3, 12-1-4), one from Site 35 (35-1-1) and one from Site 43 (43-1-2).

\section{Smittium simulii Lichtw., 1964}

Like Sm. culicis, Sm simulii has a wide dipteran host range and has been reported from North America, Europe, Japan, New Zealand and mainland Australia. In Tasmania, Sm. simulii was found in Simuliidae hindguts from Sites 4, 21, 27 and 36; in Chironomus sp. (Chironomidae) from Site 18; in Cricotopus sp. from Site 27; in Orthocladius sp. (Chironomidae) from Site 41 and from which an axenic culture, 411-6, was obtained; and in Podonomopsis sp. (Chironomidae) from Site 48. The cultured specimen appears to be $\mathrm{Sm}$. simulii, although the trichospores were larger than normal ([16-]23[-30]), measuring up to $40 \times 8 \mu \mathrm{m}$.

\section{Stachylina grandispora Lichtw., 1972}

Stachylina grandispora commonly is found attached to the peritrophic membrane of Chironomus spp. and other bloodworms in many parts of the world. It was collected from Site 18 in a Chironomus sp. larva.

Stachylina thaumaleidarum Lichtw. \& M.C. Williams, 1990

This is possibly a species endemic to Australian Thaumaleidae, having been found previously only in Victoria. Collections in Tasmania included Sites 35 and 49. Trichospores of the Tasmanian specimens measured 30-40 $\times 9-11 \mu \mathrm{m}$, whereas those in the original description from Victoria were (20-)26(-38) $\times(5.5-) 7(-8)$, thus the Tasmanian trichospores were somewhat wider. Nonetheless we believe they are the same species.

\section{KEY TO SPECIES OF HARPELLALES CURRENTLY KNOWN FROM TASMANIAN INSECT LARVAE}

1. Thallus unbranched, attached to peritrophic membrane of midgut ................. 2

1'. Thallus branched, living in the hindgut ..... 5

2. Trichospores cylindrical and curved to coiled, or sometimes straight; in midgut of Simulate .............. Harpella melusinae

2'. Trichospores always straight and not cylindrical; in midgut of Chironomidae or Thaumaleidae .................. 3

3. Trichospores $>75 \mu \mathrm{m}$ long .. Stachylina dolichospora

3'. Trichospores $<75 \mu \mathrm{m}$ long ............ 4

4. In Thaumaleidae; trichospores $<40 \mu \mathrm{m}$ long ............ Stachylina thaumaleidarum

4'. In Chironomidae; trichospores $>40 \mu \mathrm{m}$ long

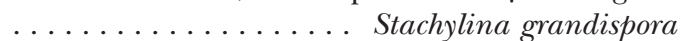

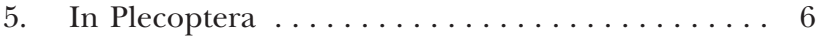

$5^{\prime}$. In Ephemeroptera or Diptera . . . . . . . . 7

6. Trichospores $12-21 \times 2-4 \mu \mathrm{m} \ldots \ldots \ldots$. ........... Plecopteromyces leptoperlarum

$6^{\prime}$. Trichospores $21-30 \times 3-5 \mu \mathrm{m} \ldots \ldots \ldots$. .......... Plecopteromyces trinotoperlarum

7. In Ephemeroptera ......... Glotzia tasmaniensis

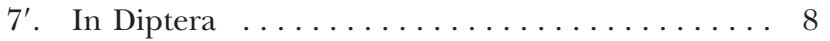

8. Trichospores without a collar and with 2-4 appendages; thalli usually attached to Paramoebidium (Amoebidiales) thalli or to other Harpellales .......... Simuliomyces microsporus

8'. Trichospores with a collar and a single appendage; always attached to hindgut cuticle . . . . . 9

9. Basal cell horseshoe-shaped; biconical zygospores bent like a boomerang, arising from two fused branches that form a wishbone-like structure .... .............. Furculomyces boomerangus

9'. Basal cell not horseshoe-shaped (except in Smittium simulii); biconical zygospores not bent and not arising from a wishbone-like set of conjugants

$\ldots \ldots \ldots \ldots \ldots \ldots \ldots \ldots \ldots \ldots \ldots \ldots \ldots \ldots \ldots \ldots$

10. Trichospores oval to ellipsoidal with one coarse appendage; biconical zygospores, if present, small $(<25 \mu \mathrm{m}$ long $)$ and swollen in the middle, and with one coarse appendage ... 11

$10^{\prime}$. Trichospores ellipsoidal to subcylindrical with one fine appendage; biconical zygospores, if present, larger (>25 $\mu \mathrm{m}$ long) and not swollen in the middle, with one fine appendage

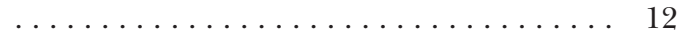

11. Trichospores dimorphic, either oval and 10-15 $\times$ 4.2-5.6 $\mu \mathrm{m}$, or ellipsoidal and 22-29 $\times 7.2-8 \mu \mathrm{m}$; zygospores unknown ...... Austrosmittium biforme

$11^{\prime}$. Trichospores monomorphic and oval, 11-16 $\times 5$ $8 \mu \mathrm{m}$; zygospores $20-25 \times 6-8 \mu \mathrm{m} \ldots \ldots \ldots$. ............. Austrosmittium aussiorum 12. Trichospores large, $>35 \mu \mathrm{m}$ long $\ldots \ldots$. ............. Smittium magnospora $12^{\prime}$. Trichospores smaller, $<35 \mu \mathrm{m}$ long . . . . . 13

13. Trichospores long-oval with a long and more or less campanulate collar; basal cell tapered to a point; 
(may be found in several families of Nematocera, lower Diptera) ............ Smittium culicis $13^{\prime}$. Trichospores more ellipsoidal or nearly cylindrical, with a cylindrical collar ............. 14 14. Trichospores small, $12-14 \times 2.5-3 \mu \mathrm{m} \ldots \ldots$ $\ldots \ldots \ldots \ldots \ldots$ Smittium paludis 14'. Trichospores larger than $18 \mu \mathrm{m} \ldots \ldots \ldots .15$

15. Trichospores almost cylindrical, 3-4 $\mu \mathrm{m}$ diam . . 16

$16^{\prime}$. Trichospores more ellipsoidal, $>4 \mu \mathrm{m}$ diam . . . 17

16. Basal cell tapered to a point ......... .............. Smittium fastigatum

$16^{\prime}$. Basal cell not tapered to a point ....... ............. Smittium typhellum

17. Thalli growing in compact clusters, with the basal cell often appearing knobby; trichospore collar usually $<3 \mu \mathrm{m}$ long ........... Smittium compactum

17 '. Thalli may be dense, but not growing in compact clusters; basal cell horseshoe-shaped; collar usually $>4 \mu \mathrm{m}$ long; (may be found in several different families of Nematocera, lower Diptera) ......

................... Smittium simulii

\section{DISCUSSION}

Gripopterygidae (Plecoptera: Antarctoperlaria) is a family of stoneflies restricted to the Southern Hemisphere. In addition to the two new species of Plecopteromyces described above, we found at Sites 38 and 39 another two different harpellid species in Gripopterygidae nymphs that possibly belong to this genus but without sufficient information on their trichospore appendages to describe and name them at this time. Assigning the two new species, $P$. leptoperlarum and $P$. trinotoperlarum, to Plecopteromyces is based on trichospore morphology and host considerations. It will be necessary to find the unique turbinate zygospores of this genus described in the type species, $P$. patagoniensis from Argentina (Lichtwardt et al 1999), to confirm the generic placement of these new species. As yet unreported (Ferrington et al pers comm) are four additional new species of Plecopteromyces that were found on South Island, New Zealand. This type of circumantarctic distribution suggests that both the hosts, which are endemic to their respective continents or islands, and their gut fungi might have had ancestral species on Gondwana and diverged vicariantly after the tectonic breakup of that ancient continent.

The discovery of trichomycete species in larvae of several new host chironomids is of particular interest and requires more discussion. Slaymaker et al (1999) reviewed Chironomidae-Trichomycete associations and recorded an unidentified species of Smittium from a Riethia sp. larva (Table 5, p 497) based on thalli growing in the hindgut. Growths of thalli, although extensive, lacked mature trichospores and zy- gospores and could not be identified. However, this provided the first recovery of a Trichomycete from the hindgut of a chironomid species of the tribe Pseudochironomini. Previously the only known Trichomycete of Pseudochironomini was Stachylina manicata M.C. Williams \& Lichtw., from a Pseudochironomus larva collected in a cattail swamp bordering Flathead Lake, Montana, by Williams and Lichtwardt (1984). The larva with thalli of Smittium in the hindgut reported by Slaymaker et al (1999) is the same specimen from which Stachylina dolichospora was recovered.

Trichomycetes of the genera Stachylina, Smittium and Trichozygospora previously have been recovered from species in three of the six tribes of Diamesinae: Boreoheptagyini (Boreoheptagyia lurida [Garrett]), Diamesini (Diamesa valkanovi Saether, Diamesa nr. nivoriunda [Fitch], Pagastia sp., Sympotthastia sp. and Syndiamesa macronyx Kieffer), and Heptagyiini ( $L i$ maya [?] sp., Maoridiamesa sp., Paraheptagyia sp. and Paraheptagyia cinerascens [Edwards]). The presence of Austrosmittium biforme in larva of Paraheptagyia sp. increases the number of genera known to be associated with Diamesinae and represents the fourth species using Heptagyini as hosts, the previous records being Smittium simulii in Maoridiamesa sp. from New Zealand (Lichtwardt and Williams 1992), Smittium cylindrosporum in Paraheptagyia cinerascens (Edwards) in Chile (Lichtwardt and Arenas 1996) and Argentina (Lichtwardt et al 1999), and Smittium tronadorium Lichtw., Ferrington \& López Lastra in Paraheptagyia sp. in Argentina (Lichtwardt et al 1999). Austrosmittium biforme also was identified from Cricotopus sp. larvae at Site 32, and Sm. tronadorium and Sm. cylindrosporum also were identified from Cricotopus sp. larvae in Argentina, demonstrating additional instances of host sharing among species of Diamesinae-Orthocladiinae as discussed by Slaymaker et al (1999).

Larvae of Podonomopsis sp. collected from Sites 30, 41 and 48 were infested with trichomycetes. Larvae from all three sites had small fungal growths, with few developing trichospores, attached at the extreme posterior edges of the hindgut. Larvae from Site 48 had nearly mature trichospores and a well developed horseshoe-shaped basal cell forming a holdfast typical of Smittium simulii, and these were the only fungal growths that could be identified. This trichomycete species infests a broad range of Diptera hosts, including Culicidae, Simuliidae, Thaumaleidae, Ceratopogonidae and Tipulidae. Slaymaker et al (1999) remarked that it had a correspondingly broad range of chironomid hosts and was the only species of trichomycetes to use hosts of Orthocladiinae, Chironomini, Tanytarsini and Diamesinae. Its occurrence in Podonomopsis sp. expands the known hosts to include 
a species in another subfamily, Podonominae, and further supports the observations of Slaymaker et al (1999).

Immature thalli that could not be identified confidently were found in several additional genera of Chironomidae but are worthy of comment due to their unusual morphologies, host associations and/ or host habitats. The larvae and sample sites are: $E \boldsymbol{u}$ kiefferiella sp. (Site 10), Pseudosmittia sp. (Site 12), Paratanytarsus sp. (Site 30), Thienemanniella sp. (Sites 24, 36 and 37) and Stictocladius sp. (Site 35). Three species of trichomycetes are known from $\mathbf{E u}$ kiefferiella larvae, Smittium coloradense M.C. Williams \& Lichtw. (1987) and Sm. ouseli M.C. Williams \& Lichtw. (1984), both isolated from larvae collected in the United States, and Smittium esteparum Ferrington, Lichtw. \& López Lastra (1999) from larvae in Argentina. The developing trichospores of the growths within the hindgut of the Eukiefferiella sp. larva collected at Site 10 do not resemble trichospores of any of the trichomycetes recorded previously for this chironomid genus, and it appears that yet another species uses this genus as a host.

Larvae of Pseudosmittia sp. collected from a small rock pool above the high tide zone at Cole's Bay (Site 12) were infested in the hindgut, but no mature trichospores were present. Larvae of this chironomid genus show a wide variety of habitat preferences that varies by species, ranging from lakes and streams to semi-aquatic habitats to moist soils. The rock pool, although above the high tide zone, was influenced by ocean spray and brackish conditions. This represents the first record of a trichomycete using Pseudosmittia as a host and suggests that both the chironomid and the fungal species are tolerant of brackish habitats. Mosquito larvae collected from the same rock pools were infested with Smittium culicis. Similarly, larvae of Cricotopus sp. collected from small, brackish, rock pools above the high tide zone at Site 42 were infested with Sm. culicis. These larvae also had small thalli attached to the peritrophic membrane in the midgut but no developing trichospores, suggesting that at least one additional species of trichomycete is tolerant of brackish habitats.

A single larva of Paratanytarsus sp. collected at Site 30 had immature trichomycete thalli present in both the midgut and hindgut. Although not identifiable, they represent the first observations of trichomycetes using this genus as a host in the Southern Hemisphere and suggest two species of fungus are involved. A previous record of an unidentified species of Stachylina in a larva of Paratanytarsus sp. from Douglas County, Kansas, was published by Slaymaker et al (1999).

Infested larvae of Thienemanniella sp. were collect- ed at three sites. Larvae at Site 24 had immature trichomycete thalli attached to the peritrophic membrane. The thalli had a branching pattern unlike other species known to use this genus as a host and certainly represent a new genus. However there was insufficient material to develop a description. Other trichomycetes recovered from the midguts of Thienemanniella larvae are Stachylina minima Williams \& Lichtwardt, a species that penetrates the peritrophic membrane of the midgut, and Stachylinoides arctata Ferrington, Lichtwardt \& López Lastra, a eucarpic species that sometimes line the entire midgut of these small chironomid larvae (Lichtwardt et al 1999). Both occur in larvae collected in Argentina. Slaymaker et al (1999) also reported an unidentified species of Stachylina in larvae of this host genus from Douglas County. Thienemanniella sp. larvae collected from Sites 36 and 37 had small, unidentifiable growths of immature thalli attached to the hindgut epithelium, representing the first recovery of a hindgut-inhabiting fungus from this host genus.

The chironomid genus Stictocladius currently is known only from the Southern Hemisphere, where it shows a circumpolar distribution with species occurring in Chile, Argentina, Australia and New Zealand (Brundin 1966). One larva collected at Site 35 was infested in both the midgut and hindgut with immature thalli that could not be identified, representing the first recovery of trichomycetes for this host genus in Tasmania. A previous record of an unidentified Smittium was provided by Slaymaker et al (1999) for larvae collected in Argentina.

This study extends our knowledge of the biodiversity, distribution and host specificity of Harpellales and supports the hypothesis that cospeciation might have occurred with some Chironomidae and perhaps other aquatic insect larvae such as the plecopteran family Gripopterygidae. Additional studies in Southern Hemisphere locations such as New Zealand or South Africa might provide data that strengthen our biogeographical concepts and support or refute the apparent endemicity of Harpellales species currently known only from Australia.

\section{ACKNOWLEDGMENTS}

We are grateful to the National Science Foundation for PEET award DEB-9521811 (R.W.L. and L.C.F., PIs) that supported the studies in 1996, and, in prior years, for NSF awards DEB-8019724 and BSR-9006368 (R.W.L., PI), and grants to M.C.W. from the University of Nebraska at Kearney Research Services Council. We are indebted to A.M.M. Richardson of Hobart for identifying stonefly nymphs. 


\section{LITERATURE CITED}

Beard CE, McCreadie JW, Adler PH. 2003. Prevalence of the trichomycete fungus Harpella melusinae (Harpellales: Harpellaceae) in larval black flies (Diptera: Simuliidae) across a heterogeneous environment. Mycologia 94:577-583.

Brundin L. 1966. Transantarctic relationships and their significance, as evidenced by chironomid midges with a monograph of the subfamilies Podonominae and Aphroteniinae and the austral Heptagyiae. Kungl Svenska Vetensk Handl 11:1-472.

Lichtwardt RW, Arenas J. 1996. Trichomycetes in aquatic insects from southern Chile. Mycologia 88:844-857.

, Cafáro MJ, White MM. 2001. The Trichomycetes, fungal associates of arthropods. Revised ed., published on the Internet, www.nhm.ku.edu/ fungi.

, Ferrington LC Jr, López Lastra C. 1999. Trichomycetes in Argentinean aquatic insect larvae. Mycologia 91:1060-1082.

, Williams MC. 1990. Trichomycete gut fungi in Australian aquatic insect larvae. Can J Bot 68:1057-1074.

$\longrightarrow, \ldots$ 1992a. Tasmanian trichomycete gut fungi in aquatic insect larvae. Mycologia 84:384-391. 1992b. Western Australian species of Smittium and other Trichomycetes in aquatic insect larvae. Mycologia 84:392-298. 1992c. Furculomyces, a new homothallic genus of Harpellales (Trichomycetes) from Australian midge larvae. Can J Bot 70:1196-1198.

Misra JK. 2000. Growth, sporulation and pH tolerance of Furculomyces boomerangus and Austrosmittium biforme in axenic culture. Mycologia 92:1051-1056.

Slaymaker AK, Ferrington LC Jr, Lichtwardt RW. 1999. Chironomidae-Trichomycete Associations: A literature review. J. Kansas Entomol. Soc. 71(4):490-500.

Williams MC, Lichtwardt RW. 1984. Two Stachylina and two Smittium species (Trichomycetes) from Montana. Mycologia 76:204-210.

— -1987 . Three new species of Smittium (Trichomycetes) with notes on range extensions. Mycologia 79:832-838.

- 1990. Trichomycete gut fungi in New Zealand aquatic insect larvae. Can J Bot 68:1045-1056.

-1 1993. A new monotypic fungal genus, $A l-$ lantomyces, and a new species of Legeriomyces (Trichomycetes, Harpellales) in the hindgut of a Western Australian mayfly nymph (Tasmanocoenis sp.). Can J Bot 71:1109-1113.

, Peterson SW. 1982. Smittium longisporum, a new Harpellales (Trichomycetes) from chironomidguts. Mycotaxon 16:167-171. 